and the proper role of courts in a constitutional system. He also perceives a significant risk that an internationalist approach to constitutional adjudication could result in undermining rather than enhancing the American approach to constitutional rights. MichaelD. Ramsey continues the critique by calling for those who would apply international sources to accept rigorous discipline in their use, involving (1) articulation of the theory of relevance of such materials; (2) acceptance of outcomes that might not necessarily support the rights-enhancing preferences of most internationalists; (3) attention to the full factual picture of international practice; and (4) avoidance of the uncritical assumption that the views of selected human rights tribunals and UN agencies represent a global consensus.

Gerald L. Neuman offers both a justification for turning to international law and practice as one available resource for constitutional interpretation, and a method for how to do so. He analyzes the relationship between international human rights law and constitutional interpretation in terms of their consensual, suprapositive, and institutional characteristics, so that a serious inquiry into international sources can inform a domestic court as it strives for the most complete understanding of complex problems that recur in democratic societies around the world. Finally, T. Alexander Aleinikoff seeks to move beyond the existing debates on the place of international law in the.U.S. legal system, by advocating congressional enactment of a new "Incompatibility Statute" modeled on the British Human Rights Act, which would allow for judicial determinations of inconsistencies between U.S. federal law and international law and facilitate efforts to ensure compliance with the international obligations of the United States.

Our hope is that the viewpoints expressed in this forum not only will contribute to the ongoing dialogue in this country about the relevance of international sources to domestic legal questions, but also will help our foreign readership reach a fuller understanding of the complex interactions of international law and constitutional law in the United States.

\title{
INTERNATIONAL LAW AS PART OF OUR LAW
}

\section{By Harold Hongju Koh ${ }^{*}$}

What did the United States Supreme Court mean when it famously said, "International law is part of our law, and must be ascertained and administered by the courts of justice of appropriate jurisdiction, as often as questions of right depending upon it are duly presented for their determination"?' Perhaps the Court was suggesting that, in an interdependent world,

\footnotetext{
* Of the Board of Editors. The author served as Counsel of Record for Mary Robinson, et al., Amici Curiae, in Lawrence v. Texas (arguing that statutes criminalizing same-sex sodomy violate the concept of "ordered liberty" in Due Process and Equal Protection clauses), and for U.S. Diplomats Morton Abramowitz, et al., Amici Curiae, in McCarverv. North Carolina, No. 00-8727 (U.S. cert. dismissed Sept. 25, 2001), and in Atkins v. Virginia (arguing that execution of those with mental retardation violates Eighth Amendment's cruel and unusual punishments clause). Special thanks to Gerald Neuman, for his insight; to Kenji Yoshino, Ryan Goodman, Robert Wintemute, and an extraordinary group of Yale Law students who worked with me on those amicus briefs; and to Allon Kedem for his fine research assistance.

${ }^{1}$ The Paquete Habana, 175 U.S. 677, 700 (1900). Five years earlier, in Hilton v. Guyot, 159 U.S. 113 (1895), Justice Gray explained in more detail:

International law, in its widest and most comprehensive sense-including not only questions of right between nations, governed by what has been appropriately called the law of nations; but also questions arising under what is usually called private international law, or the conflict of laws, and concerning the rights of persons within the territory and dominion of one nation, by reason of acts, private or public, done within the dominions of another nation-is part of our law, and must be ascertained and administered by the courts of justice, as often as such questions are presented in litigation between man and man, duly submitted to their determination.
}

Id. at 163 . 
United States courts should not decide cases without paying "a decent respect to the opinions of mankind," in the memorable words of the Declaration of Independence. ${ }^{2}$ The framers and early Justices understood that the global legitimacy of a fledgling nation crucially depended upon the compatibility of its domestic law with the rules of the international system within which it sought acceptance ${ }^{3}$ Their recognition seems both prudent and sensible. Even today, for any nation consciously to ignore global standards not only would ensure constant frictions with the rest of the world, but also would diminish that nation's ability to invoke those international rules that served its own national purposes. ${ }^{4}$

Not surprisingly, the early Supreme Court saw the judicial branch as a central channel for making international law part of U.S. law. ${ }^{5}$ The original design and early practice of our courts envisioned that they would not merely accept, but would actively pursue, an understanding and incorporation of international law standards out of a decent respect for the opinions of mankind. When "there is no written law upon the subject," Justice Horace Gray directed, "the duty still rests upon the judicial tribunals of ascertaining and declaring what the law is, whenever it becomes necessary to do so, in order to determine the rights of parties to suits regularly brought before them." ${ }^{6}$ By so saying, he echoed Chief Justice John Marshall's memorable cadence in Marbury $v$. Madison: "[i] $\mathrm{t}$ is emphatically the province and duty of the judicial department to say what the law is," a directive that nowhere limited the judiciary's law-declaring function to cases involving domestic law.

Thus, many of Marshall's early opinions expressly promoted the implicit or explicit internalization of international law into U.S. domestic law: through statutory construction, direct invocation, and even constitutional interpretation. Within a year after writing Marbury, for example, Chief Justice Marshall ruled in The Charming Betsy that "an act of Congress ought never to be construed to violate the law of nations if any other possible construction remains."

\footnotetext{
${ }^{2}$ THE DECLARATION OF INDEPENDENCE, para. 1 (U.S. 1776) ("When in the Course of human Events, it becomes necessary for one People to dissolve the Political Bonds which have connected them with one another, ... a decent Respect to the Opinions of Mankind requires that they should declare the causes which impel them to the Separation.") (emphasis added).

${ }^{3}$ The author of the Declaration, Thomas Jefferson, heralded the law of nations as "an integral part . . . of the laws of the land." Letter from Thomas Jefferson, Secretary of State, to M. Genet, French Minister (June 5, 1793), quoted in 1 JOHN BASSETT MOORE, DIGEST OF INTERNATIONAL LAW 10 (1906). In John Jay's words, "the United States had, by taking a place among the nations of the earth, become amenable to the law of nations." Chisholm $v$. Georgia, 2 U.S. (2 Dall.) 419, 474 (1793); see Ware v. Hylton, 3 U.S. (3 Dall.) 199, 281 (1796) (Wilson, J.) ("When the United States declared their independence, they were bound to receive the law of nations, in its modern state of purity and refinement."); see also 1 Op. Att'y Gen. 26 (1792) (opinion of Attorney General Randolph) ("The law of nations, although not specially adopted by the constitution, or any municipal act, is essentially a part of the law of the land.").

${ }^{4}$ Witness, for example, the first acts of East Timor's newly elected eighty-eight-member Parliament: signing the Universal Declaration of Human Rights and applying to join the United Nations. East Timor Becomes 191st U.N. Member Today, N.Y. Times, Sept. 27, 2002, at A11. See also President Xanana Gusmão, Address to the United Nations General Assembly on East Timor's New Membership, UN Doc. A/57/P.V.20, at 10, 11-12 (2002), stating:
}

We are aware that we will be serving the interests of our people only if we honour our international commitments by signing the relevant conventions and treaties which not only safeguard our sovereignty and our interests but also respect the sovereignty and interests of other peoples and States, particularly those of our region.

${ }^{5}$ See RESTATEMENT (THIRD) OF THE FOREIGN RELATIONS LAW OF THE UNITED STATES $\$ 111$ introductory note (1987) ("From the beginning, the law of nations, later referred to as international law, was considered to be incorporated into the law of the United States without the need for any action by Congress or the President, and the courts, State and federal, have applied it and given it effect as the courts of England had done.") (emphasis added); Louis Henkin, The Constitution and United States Sovereignty: A Century of Chinese Exclusion and Its Progeny, 100 HARV. L. REV. 853, 868 (1987) ("[E]arly United States courts and legislators regarded customary international law and treaty obligations as part of the domestic legal system. International law was domestic law.") (emphasis in original). For a fuller discussion of the judicial branch as a channel of internalization of international norms into U.S. law, see generally Harold Hongju Koh, Is International Law Really State Law? 111 HARV. L. REv. 1824 (1998).

${ }^{6}$ Hilton v. Guyot, 159 U.S. at 163 (emphasis added).

${ }^{7} 5$ U.S. (1 Cranch) 137, 177 (1803).

${ }^{8}$ Murray v. The Schooner Charming Betsy, 6 U.S. (2 Cranch) 64, 118 (1804). 
Eleven years later, he clarified that absent a contrary statute, "the Court is bound by the law of nations which is a part of the law of the land." In McCulloch v. Maryland, Chief Justice Marshall suggested that mankind's views are also relevant to the task of constitutional interpretation, noting:

If any one proposition could command the universal assent of mankind, we might expect it would be this-that the government of the Union, though limited in its powers, is supreme within its sphere of action....

... In considering this question, then, we must never forget, that it is a constitution we are expounding. ${ }^{10}$

Significantly, at the beginning of the Republic, U.S. courts drew no sharp line between international and foreign law, precisely because of the extensive overlap of these two bodies of law. Customary rules like lex mercatoria and the criminal prohibition against piracies and felonies on the high seas were both "international," in the sense of governing transboundary transactions, and "foreign," in the sense of being internalized into the domestic law of foreign legal systems, as well as that of the United States. ${ }^{11}$ It was thus often difficult to distinguish when American courts were treating "international" or "foreign" law as part of our law. Some rules were inherently "transnational," hence not easily categorized as local or global in nature.

From the beginning, then, American courts regularly took judicial notice of both international law and foreign law (the law and practice of other nations) when construing American law. Given this historical tradition, should United States constitutional interpretation now ignore international law standards and the practices of other countries? Remarkably, some offer reasons why it should. ${ }^{12}$ But such an approach would constitute a stunning reversal of history.

When is it appropriate for the Supreme Court to construe our Constitution in light of foreign and international law? History suggests that over the years, the Court has regularly looked to foreign and international precedents as an aid to constitutional interpretation in at least three situations, which for simplicity's sake I will call "parallel rules," "empirical light," and "community standard." First, the Court has noted when American legal rules seem to parallel those of other nations, particularly those with similar legal and social traditions. ${ }^{13}$ As the Court has repeatedly recognized, the concept of "ordered liberty" is not uniquely American but, rather, is "enshrined" in the legal history of "English-speaking peoples," as well as other legal systems. ${ }^{14}$

\footnotetext{
${ }^{9}$ The Nereide, 13 U.S. (9 Cranch) 388, 423 (1815); see also The Schooner Exchange v. M'Faddon, 11 U.S. (7 Cranch) 116 (1812) (declaring international rule of absolute foreign sovereign immunity as U.S. law).

${ }^{10} 17$ U.S. (4 Wheat.) 316, 405-07 (1819) (emphasis added).

"SeeHarold Berman \& Colin Kaufman, The Law of Intermational Commercial Transactions (Lex Mercatoria), 19 HARV. INT'L L.J. 221, 224-29 (1978) (law merchant was transnational private law based not on any single national law but on mercantile customs generally accepted by trading nations); Edwin D. Dickinson, The Law of Nations as Part of the National Law of the United States (pt. 1), 101 U. PA. L. REv. 26, 26-27 (1952).

${ }^{12}$ See, e.g., Roger P. Alford, Misusing International Sources to Interpret the Constitution, 98 AJIL 57 (2004) [hereinafter Alford, Misusing Sources]; Roger P. Alford, Federal Cousts, International Tribunals, and the Continuum of Deference, 43 VA. J. INT'L L. 675 (2003) [hereinafter Alford, Federal Courts]; Michael D. Ramsey, International Materials and Domestic Rights: Reflections on Atkins and Lawrence, 98 AJIL 69 (2004).

${ }^{13}$ See, e.g., Reynolds v. United States, 98 U.S. 145, 164 (1878) (pointing out that "[p]olygamy has always been odious among the northern and western nations of Europe").

${ }^{14}$ See, e.g., Ingraham v. Wright, 430 U.S. 651, 673 n.42 (1977) (quoting Wolf v. Colorado, 338 U.S. 25, 27-28 (1949)); Miranda v. Arizona, 384 U.S. 436, 488 n.59, 521-22 (1966) (quoting from a 1954 decision by the lord justice general of India and citing the experiences in other countries); Poe v. Ullman, 367 U.S. 497, 548 (1961) (Harlan, $\mathrm{J}$, dissenting) (delimiting the notion of privacy in the home by looking to "common understanding throughout the English-speaking world"); Quinn v. United States, 349 U.S. 155, 167 (1955) (finding a practice "supported by long-standing tradition here and in other English-speaking nations"); Rochin v. California, 342 U.S. 165,169 (1952) (writing that the Due Process Clause obliges courts to ascertain whether a given law or practice offends "those canons
} 
Second, as Justice Stephen Breyer recently noted, the "Court has long considered as relevant and informative the way in which foreign courts have applied standards roughly comparable to our own constitutional standards in roughly comparable circumstances. ${ }^{~}{ }^{15}$ In Printz $v$. United States, he elaborated:

Of course, we are interpreting our own Constitution, not those of other nations, and there may be relevant political and structural differences between their systems and our own. . . But their experience may nonetheless cast an empirical light on the consequences of different solutions to a common legal problem-in this case the problem of reconciling central authority with the need to preserve the liberty-enhancing autonomy of a smaller constituent governmental entity. ${ }^{16}$

Third, in addition to situations involving parallel rules and empirical lessons, the Court has looked outside the United States when a U.S. constitutional concept, by its own terms, implicitly refers to a community standard-e.g., "cruel and unusual," "due process of law," "unreasonable searches and seizures." In such cases, the Court has long since recognized that the relevant communities to be consulted include those outside our shores. For example, in deciding whether a particular punishment has become both "cruel and unusual," the Court has long taken notice of foreign and international practice to evaluate how "unusual" the practice has become. ${ }^{17}$ In Trop v. Dulles, the Court specifically held that the Eighth Amendment to the United States Constitution contains "evolving standards of decency that mark the progress of a maturing society." 18 In Tropand subsequent cases, the Court made clear that this "evolving standard" should be measured by reference not just to maturing American experience, but to foreign and international experience as well.

In Coker v. Georgia ${ }^{19}$ for example, the Court determined that international practices regarding the death penalty for rape were relevant to its "evolving standards" analysis. Five years later, in Enmund v. Florida, the Court noted that "the doctrine of felony murder has been abolished in England and India, severely restricted in Canada and a number of other Commonwealth countries, and is unknown in continental Europe:" ${ }^{20}$ In Thompson v. Oklahoma, ${ }^{21}$ following the reasoning of Trop, Justice John Paul Stevens's plurality opinion invalidated the death penalty for fifteen-year-old offenders, evaluating the Eighth Amendment's "civilized standards of decency" in part by looking to the prohibition of the execution of minors by the Soviet Union and nations of Western Europe. ${ }^{22}$ In addition, both the plurality and Justice Sandra Day O'Connor's concurrence found significant that three major international human

of decency and fairness which express the notions of justice of English-speaking peoples"); Rast v. Van Deman \& Lewis Co., 240 U.S. 342, 366 (1916) (observing that the Constitution embodies "only relatively fundamental rules of right, as generally understood by all English-speaking communities"). Happily, over time, the Court has relaxed its "Anglophonia" and spoken more broadly about "civilized societies," without regard to the particular language they may speak. See, e.g., Ford v. Wainwright, 477 U.S. 399, 409 (1986) (noting "the natural abhorrence civilized societies feel at killing one who has no capacity to come to grips with his own conscience or deity") (emphasis added).

${ }^{15}$ Knight v. Florida, 528 U.S. 990, 997 (1999) (Breyer, J., dissenting from denial of certiorari).

${ }^{16} 521$ U.S. 898, 921 n.11, 977 (1997) (Breyer, J., dissenting) (citations omitted) (emphasis added).

${ }^{17}$ As Justice Blackmun noted, "If the substance of the Eighth Amendment is to turn on the 'evolving standards of decency' of the civilized world, there can be no justification for limiting judicial inquiry to the opinions of the United States." Harry A. Blackmun, The Supreme Court and the Law of Nations, 104 YALE L.J. 39, 48 (1994); cf. Estelle v. Gamble, 429 U.S. 97, 102 (1976) (observing that the Eighth Amendment's bar against cruel and unusual punishments embodies broad evolving "concepts of dignity, civilized standards, humanity and decency") (emphasis added). For a review of this history, see Harold Hongu Koh, Paying "Decent Respect" to World Opinion on the Death Penalty, 35 U.C. DAVIS L. REV. 1085, 1118-27 (2002), from which some of the discussion in the text derives.

18356 U.S. 86,101 (1958).

19433 U.S. 584,596 n. 10 (1977).

${ }^{20} 458$ U.S. 782,796 n.22 (1982).

${ }^{21} 487$ U.S. 815,830 (1988).

${ }^{22}$ Justice Stevens noted the views of "other nations that share our Anglo-American heritage, and ... the leading members of the Western European community." Id. at 829-30, 829 n.30. 
rights treaties-including, in its Article 68, the 1949 Geneva Convention, which the United States had ratified-explicitly prohibited juvenile death penalties. ${ }^{23}$

Thompson's reliance on foreign precedent drew a vigorous dissent from Justice Antonin Scalia, who denounced the plucality's reliance on international practice as "totally inappropriate." "[T] he views of other nations, however enlightened the Justices of this Court may think them to be," he argued, "cannot be imposed upon Americans through the Constitution." 24 But given the foregoing history, Justice Scalia erred in at least four ways. First, that history should have led a justice devoted to originalism to look, like the framers themselves, toward-not away from-international opinion. Second, far from "imposing" the views of other nations on Americans, an originalist reading of the Eighth Amendment would have acknowledged that the views of other nations were not imposed on early Americans; rather, Americans selfconsciously appealed to those views in order to win global legitimacy for their fledgling republic. Third, on reflection, it makes little constitutional sense for our Supreme Court to decide these cases in a vacuum. The United States has never been a hermetically sealed legal system. It shares a common legal heritage, tradition, and history with many foreign constitutional systems. For that reason, constitutional concepts like "liberty," "equal protection," "due process of law," and privacy have never been exclusive U.S. property, but have long carried global meaning. ${ }^{25}$ To construe these terms in ignorance of these foreign and international precedents virtually ensures that our Supreme Court rulings will generate conflict and controversies with our closest global allies. Conversely, to construe these terms in light of foreign interpretations allows the United States to use the experience of other nations that share its common constitutional genealogy as laboratories to test workable social solutions to common constitutional problems. ${ }^{26}$

Fourth and finally, Justice Scalia himself has been far from consistent in insisting upon the irrelevance of foreign and international law. Depending upon the factual setting, he has not hesitated to take foreign practice into account or to argue in favor of construing U.S. law consistently with principles of international law. ${ }^{27}$ Nevertheless, one year after Thompson, Justice Scalia narrowly carried the day in Stanford v. Kentucky, when a 5-4 majority of the Court held that, notwithstanding international opinion, the Eighth Amendment does not prohibit the execution of juvenile offenders who committed their crimes at age sixteen. ${ }^{28}$ Justice Scalia's opinion announcing the Court's judgment, joined without comment by Justice O'Connor, applied the methodology of his Thompson dissent. Refusing to examine the juvenile sentencing practices of other countries, he asserted that in determining contemporary standards of

${ }^{23}$ Id. at 831 n.34; id. at 851 (O'Connor, J., concurring in the judgment) (citing American Convention on Human Rights, Nov. 22, 1969, Art 4(5), 1144 UNTS 123 (entered into force July 18, 1978); International Covenant on Civil and Political Rights, Dec. 19, 1966, Art. 6(5), 999 UNTS 171, 175 (entered into force Mar. 23, 1976) [hereinafter ICCPR]; Geneva Convention Relative to the Protection of Civilian Persons in Time of War, Aug. 12, 1949, Art. 68, 6 UST $3516,3560,75$ UNTS 287, 330 (entered into force Oct. 21, 1950)) . Justice O'Connor's concurrence invoked the U.S. ratification of the Geneva Convention "to undercut any assumption that [recent congressional legislation has intended] to authorize the death penalty for some 15-year-old felons." Id. at 852.

${ }^{24} I d$. at 868 n.4 (Scalia, J., dissenting).

${ }^{25}$ Cf. Malinskiv. New York, 324 U.S. 401, 413-14 (1945) (Frankfurter, J., concurring) (arguing: "The safeguards of 'due process of law' and 'the equal protection of the laws' summarize the history of freedom of English-speaking peoples running back to Magna Carta and reflected in the constitutional development of our people.").

${ }^{26}$ Cf. New State Ice Co. v. Liebmann, 285 U.S. 262, 310-11 (1932) (Brandeis, J., dissenting) (noting that states of the United States can "serve as . . laborator[ies]" for "social and economic experiments").

${ }^{27}$ See, e.g., McIntyre v. Ohio Election Comm'n, 514 U.S. 334, 381 (1995) (Scalia, J., dissenting) (observing that Australian, Canadian, and English statutes banning anonymous campaign speech suggest that such bans need not impair democracy); Hartford Fire Ins. Co. v. California, 509 U.S. 764, 820 (1993) (Scalia, J., dissenting) (opposing the assertion of extraterritorial jurisdiction by Congress over antitrust defendants' foreign activity on the ground that "this and other courts have frequently recognized that ... statutes should not be interpreted to regulate foreign persons or conduct if that regulation would conflict with principles of international law").

${ }^{28} 492$ U.S. 361 (1989). 
decency, "it is American conceptions of decency that are dispositive." Justice William J. Brennan, now dissenting for the four members of the Thompson plurality, countered with a "community standard" rationale: "objective indicators of contemporary standards of decency in the form of legislation in other countries [are] also of relevance to Eighth Amendment analysis. . . . Within the world community, the imposition of the death penalty for juvenile crimes appears to be overwhelmingly disapproved." 30

For more than a decade, a slim Court majority clung to this blinkered view in death penalty cases. Yet during the same period, nearly every member of the Court wrote or joined opinions using foreign practice or precedent to illuminate interpretations of the United States Constitution. ${ }^{31}$ Ironically, within months of the Court's pronouncement in Stanford, even Chief Justice William Rehnquist suggested in extrajudicial writing:

For nearly a century and a half, courts in the United States exercising the power of judicial review had no precedents to look to save their own, because our courts alone exercised this sort of authority. When many new constitutional courts were created after the Second World War, these courts naturally looked to decisions of the Supreme Court of the United States, among other sources, for developing their own law. But now that constitutional law is solidly grounded in so many countries, it is time that the United States courts begin looking to the decisions of other constitutional courts to aid in their oum deliberative process. ${ }^{32}$

Variations on the Chief Justice's theme have been sounded with increasing vigor by Justices Breyer, Ruth Bader Ginsburg, O'Connor, and Anthony Kennedy in various speeches and other extrajudicial statements. ${ }^{39}$

During the last two Supreme Court Terms, promising signs have emerged that the American ostrich is finally starting to take its head out of the sand. In Atkins $v$. Virginia, the Court signaled its willingness to cite foreign and international law practice, holding that execution of

${ }^{29}$ Id. at 369 n.1. Although Justice O'Connor joined part I of Justice Scalia's Stanford opinion, which included his dismissive footnote, her concurrence made no mention of it. Instead, her separate opinion explicitly applied the Thompson standard and concluded that no national consensus yet forbade the imposition of capital punishment on sixteen- and seventeen-year-old offenders. Id. at 382.

${ }^{30}$ Id. at 389-90 \& n.9 (Brennan, J., dissenting) (citing Amnesty International brief).

${ }^{31}$ See cases cited supra notes 15, 22, 23, 27; see also Nixon v. Shrink Mo. Gov't PAC, 528 U.S. 377,403 (2000) (Breyer, J., concurring) (finding the Court's First Amendment jurisprudence consistent with decisions of the European Court of Human Rights and the Canadian Supreme Court); Raines v. Byrd, 521 U.S. 811 , 828 (1997) (Souter, J., concurring) (examining Dutch constitutional practice on physician-assisted suicide); Holder v. Hall, 512 U.S. 874 , 906 n. 14 (1994) (Thomas, J., concurring) (mentioning voting systems of Belgium, Cyprus, Lebanon, New Zealand, West Germany, and Zimbabwe in assessing race consciousness in the American voting system); Metro Broad., Inc. v. FCC, 497 U.S. 547, 633 n.1 (1990) (Kennedy, J., dissenting) (likening the government's racial classifications in minority-owned broadcasting enhancement scheme to practices of Nazi Germany and South Africa); United States v. Stanley, 483 U.S. 669, 710 (1987) (O'Connor, J., concurring in part and dissenting in part) (relying on Nuremberg Military Tribunals in arguing against medical experimentation on humans without their consent).

${ }^{32}$ William H. Rehnquist, Constitutional Courts-Comparative Remarks (1989), reprinted in GERMANYAND ITS BASIC LAW: Past, Present ANd FUTURE-A German-AMERICANSMmPosium 41 1, 412 (Paul Kirchhof \& Donald P. Kommers eds., 1993) (emphasis added); see also Washington v. Glucksberg, 521 U.S. 702, 710, 718 n.16, 785-87 (1997) (Rehnquist, C.J.) (declaring that "[i]n almost every State-indeed, in almost every western democracy-it is a crime to assist a suicide," noting that "other countries are embroiled in similar debates" concerning physician-assisted suicide, and citing the Supreme Court of Canada, the British House of Lords Select Committee on Medical Ethics, New Zealand's Parliament, the Australian Senate, and Colombia's Constitutional Court); Raines v. Byrd, 521 U.S. 811,828 (1997) (Rehnquist, C.J.) (noting European law on legislative standing but declining to find it in our constitutional regime); Planned Parenthood v. Casey, 505 U.S. 833, 945 n.1 (1992) (Rehnquist, C.J., concurring in part and dissenting in part) (citing abortion decisions by the West German Constitutional Court and the Canadian Supreme Court).

${ }^{33}$ Justice Breyer in particular has cogently argued in favor of reviving the use of foreign and international law precedent to inform U.S. constitutional interpretation in all three kinds of cases: those involving parallel rules, empirical lessons, and an evolving community standard. See, e.g., Stephen Breyer, Keynote Address, 97 ASIL. Proc. 265 (2003); Ruth Bader Ginsburg \& Deborah Jones Merritt, Affirmative Action: An International Human Rights Dialogue, Fifty-first Cardozo Memorial Lecture (Feb. 1 1, 1.999), in 21 CARDOzoL. REV. 253, 282 (1999); Sandra Day O'Connor, Keynote Address, 96 ASIL PROC. 348, 350 (2002) (stating that "[a]lthough international law and the law of other nations are rarely binding upon our decisions in U.S. courts, conclusions reached by other countries and by the international community should at times constitute persuasive authority in American courts," and that "there is much to learn from other distinguished jurists who have given thought to the same difficult issues that we face here"). 
persons with mental retardation would offend civilized standards of decency, in part because "within the world community, the imposition of the death penalty for crimes committed by mentally retarded offenders is overwhelmingly disapproved." ${ }^{34}$ Only a few months later, in Patterson v. Texas, Justices Stevens, Ginsburg, and Breyer dissented from denial of certiorari in a case challenging Texas's execution of a juvenile offender, noting that "the issue has been the subject of further debate and discussion both in this country and in other civilized nations," which had produced an "apparent consensus ... among the States and in the international community against the execution of a capital sentence imposed on a juvenile offender." ${ }^{35} \mathrm{Sim}$ ilarly, when the petitioner in the 1989 Stanford case-still on death row after twenty yearspetitioned the Supreme Court for an original writ of habeas corpus, citing Atkins, Justices Stevens, David Souter, Ginsburg, and Breyer all dissented from the Court's denial of the petition. ${ }^{36}$ On the same day, Justice Breyer separately dissented from a denial of certiorari, arguing that Atkins's consideration of foreign law required reexamination of whether prolonged incarceration on death row constituted cruel and unusual punishment per se. ${ }^{37}$

Writing soon thereafter, one commentator tried to dismiss this trend, noting that "Atkins presented the Supreme Court with an invitation to begin the process of internalizing global norms against the death penalty, and give "new energy to "vertical" efforts to internalize international law norms into domestic constitutional law.' But the Supreme Court declined the invitation." ${ }^{38}$ But no one could say the same after this past year's Supreme Court Term, when the relevance of foreign and international law to constitutional interpretation arose during the Term's two most publicized cases. During oral argument in the Michigan affirmative action cases, Justice Ginsburg asked the solicitor general:

[W] e're part of a world, and this problem is a global problem. Other countries operating under the same equality norm have confronted it. Our neighbor to the north, Canada, has, the European Union, South Africa, and they have all approved this kind of, they call it positive discrimination. ... [T] hey have rejected what you recited as the ills that follow from this. Should we shut that from our view at all or should we consider what judges in other places have said on this subject? ${ }^{39}$

Several months later, Justice Ginsburg answered her own question in a concurring opinion that invoked a view she had expressed in her extrajudicial writings. ${ }^{40}$ Writing in Grutter $v$. Bollinger, Justice Ginsburg, joined by Justice Breyer, pointed out, “[ $\mathrm{t}]$ he Court's observation that race-conscious programs 'must have a logical end point,' accords with the international understanding of the office of affirmative action," citing the text of the International Convention on the Elimination of All Forms of Racial Discrimination, which was ratified by the United States in $1994 .^{41}$

\footnotetext{
${ }^{34}$ Atkins v. Virginia, 536 U.S. 304, 316 n.21 (2002) (Stevens, J.). Even this modest truism evoked remarkably harsh rejoinders from the dissenters, Chief Justice Rehnquist and Justice Scalia, who again insisted that "the viewpoints of other countries simply are not relevant" to an assessment of U.S. constitutional standards. Id. at 325 (Rehnquist, C.J., dissenting).

${ }^{35}$ Patterson v. Texas, 536 U.S. 984, 984 (2002) (Stevens, J., dissenting).

${ }^{36}$ In re Stanford, 123 S.Ct. 472, 472-73 (2002) (Stevens, J., dissenting). In June 2003, the governor of Kentucky announced that he would commute Stanford's death sentence. At that point, Stanford had been on death row for two decades for a crime he had committed when he was seventeen. See Andrew Wolfson, Patton Pardons 4 in Election Case and Will Commute Death Sentence; Stanford's Family Celebrates; Victim's Sister Is Repulsed, CourIER-J., June 19, 2003, at 1A.

${ }^{87}$ Foster v. Florida, 123 S.Ct. 470, 471-72 (2002) (Breyer, J., dissenting).

${ }^{38}$ Alford, Federal Courts, supra note 12, at 782.

${ }^{39}$ Transcript of Oral Argument at 24, Gratz v. Bollinger, 123 S.Ct. 2411 (2003) (No. 02-516), available in 2003 U.S. TRANS LEXIS 27.

${ }^{40}$ Compare Grutter v. Bollinger, 539 U.S. 309, 342 (2003) (Ginsburg, J., concurring), with Ginsburg \& Merritt, supra note 33, at 282 ("In my view, comparative analysis emphatically is relevant to the task of interpreting constitutions and enforcing human rights. We are the losers if we neglect what others can tell us about endeavors to eradicate bias against women, minorities, and other disadvantaged groups.").

${ }^{41}$ Grutter, 539 U.S. at 342 (citation omitted)
} 
Just three days later, in the landmark case of Lawrencev. Texas, ${ }^{42}$ the Supreme Court struck down a Texas law banning consensual sodomy between adults of the same sex. Remarkably, the Court did not simply overrule its infamous seventeen-year-old decision in Bowers v. Hardwick ${ }^{43}$ it announced that Bowers had been wrong when decided. ${ }^{44}$ Significantly, the Supreme Court had decided Bowers without even mentioning Dudgeon $v$. United Kingdom, issued five years earlier by the European Court of Human Rights, which had rejected same-sex sodomy prohibitions as a violation of the European Convention's right to privacy. ${ }^{45}$ Dudgeon was never acknowledged by, distinguished by, or even properly cited to the Bowers Court. ${ }^{46}$ Since Bowers, the European Court of Human Rights had reaffirmed the Dudgeon decision not once, but twice: in 1988 in Norris $v$. Ireland, and five years later in Modinos v. Cyprus. ${ }^{47}$

Writing for the Court in Lawrence, Justice Kennedy took note of this parallel precedent, declaring:

To the extent Bowers relied on values we share with a wider civilization, it should be noted that the reasoning and holding in Bowers have been rejected elsewhere. The European Court of Human Rights has followed not Bowers but its own decision in Dudgeon v. United Kingdom. . . Modinos v. Cyprus, ... [and] Norris v. Ireland. . . O Other nations, too, have taken action consistent with an affirmation of the protected right of homosexual adults to engage in intimate, consensual conduct. See Brief for Mary Robinson, et al. as Amici Curiae 11-12.The right the petitioners seek in this case has been accepted as an integral part of human freedom in many other countries. There has been no showing that in this country the governmental interest in circumscribing personal choice is somehow more legitimate or urgent. ${ }^{48}$

Despite nearly a half century of coexistence between the United States Supreme Court and the European Court of Human Rights (ECHR), Lawrence was the first U.S. Supreme Court majority opinion ever to cite an ECHR judgment in the text of its opinion. Moreover, as Gerald Neuman has noted, the pages cited by Justice Kennedy in the Mary Robinson amicus brief to support the proposition that " $[0]$ ther nations ... have taken action consistent with an affirmation of the protected right of homosexual adults to engage in intimate, consensual conduct" describe how in 1994 the Australian Parliament had exercised its constitutional power to implement the United Nations Human Rights Committee's interpretation of the International Covenant on Civil and Political Rights to override a contrary Tasmanian law. ${ }^{49}$

Some therefore suggest that Laurence marks a striking departure in U.S. constitutional interpretation. But what this ignores is that, in fact, both the U.S. Supreme Court dissent ${ }^{50}$ and the

42 123 S.Ct. 2472 (2003).

${ }^{43} 478$ U.S. 186 (1986).

${ }^{44} 123$ S.Ct. at 2484.

${ }^{45} 45$ Eur. Ct. H.R. (ser. A) para. 41 (1981). The Court found the asserted state interests insufficient to justify the "detrimental effects which the very existence of the legislative provisions in question can have on the life of a person of homosexual orientation." Id., para. 60.

${ }^{46}$ The only brief in Bowers to cite European precedent had cited the European Commission of Human Rights report and pleadings in Dudgeon, but never cited or referred to the Court's judgment. See Brief of Amici Curiae Lambda Legal Defense and Education Fund at $15 \mathrm{nn} .10$, 24, Bowers v. Hardwick. 478 U.S. 186 (1986) (No. 01-102). Thus, as Lord Lester of Herne Hill has noted, although Bowers turned on a single vote, "[n]o one drew the [U.S.] Supreme Court's attention to the importance of Dudgeon as a recent decision by the strongest international court of human rights, dealing with a closely analogous problem, and having potential persuasive value." Anthony Lester, The Overseas Trade in the American Bill of Rights, 88 CoLUM. L. REV. 537, 560 (1988); see also Richard B. Lillich, The Constitution and International Human Rights, 83 AJIL 851 (1989).

${ }^{47}$ Norris v. Ireland, 142 Eur. Ct. H.R. (ser. A) (1988); Modinos v. Cyprus, 259 Eur. Ct. H.R. (ser. A) (1993).

${ }^{48}$ Laurence, 123 S.Ct. at 2483.

${ }^{49}$ Gerald L. Neuman, The Uses of International Law in Constitutional Interpretation, 98 AJIL 82, 89-90 \& n.40 (2004) (noting Human Rights Committee's interpretation in Toonen v. Australia, Communication No. 488/1992, UN Doc. CCPR/C/50/D/488/1992 (1994)).

${ }^{50}$ Justice Scalia's dissent looked to Canadian law to invoke the specter of "judicial imposition of homosexual marriage, as has recently occurred in Canada." Lawrence, 123 S.Ct. at 2497 (citing Halpern v. Toronto, 2003 WL 34950 (Ont. Ct. App. June 10, 2003)). 
lower court in Lawrence had also invoked foreign comparisons. The Supreme Court simply used foreign legal evidence to challenge assumptions that the lower court had accepted without analysis. For example, to justify its ruling upholding the Texas sodomy statute, the Texas Court of Appeals had cited ancient Roman law, Blackstone, and Montesquieu to support the claim that "Western civilization has a long history of repressing homosexual behavior by state action." ${ }^{51}$ Yet incredibly, in making that assertion, the court took no notice of any judicial decision from any modern Western civilization, when all of Europe, for example, had for more than two decades taken the opposite view. Similarly, in Bowers, Chief Justice Warren Burger had claimed in concurrence that " $[t]$ o hold that the act of homosexual sodomy is somehow protected as a fundamental right would be to cast aside millennia of moral teaching," 52 oblivious to the fact that, six years earlier, the European Court had already cast that teaching aside for what are now more than 800 million citizens of forty-five member states of the Council of Europe!

After Grutterand Lawrence, what can now be said about the role of foreign and international law in U.S. constitutional interpretation? One obvious question is whether and how extensively the Court will apply its method in Lawrence to other constitutional contexts, particularly the death penalty. Only weeks after Lawrence was decided, one federal district judge cited it, together with Atkins, to question whether the federal death penalty can be reconciled with the constitutional barrier against executing persons who are actually innocent. ${ }^{53}$ In particular, the Lawrence approach clearly now runs on a collision course with America's continuing penchant for executing juvenile offenders.

In 1979 representatives of the U.S. Department of State represented to Congress that juvenile execution was no longer a practice engaged in by the United States. ${ }^{54}$ But a year after invalidating capital punishment for fifteen-year-olds in Thompson v. Oklahoma, the Court in Stanford $v$. Kentucky arbitrarily concluded that the Eighth Amendment does not prohibit the execution of sixteen-year-old juvenile offenders. When the rest of the nations of the world ratified the Convention on the Rights of the Child-which only the United States and Somalia have declined to do-they committed themselves to banning executions of offenders under the age of eighteen. It thus became inevitable that the United States would soon stand virtually alone in openly executing juvenile offenders.

As expected, since 1989 the United States has carried out more publicly reported executions of juvenile offenders than any other country. In 1999 the only country besides the United States to admit to executing a juvenile offender was Iran. ${ }^{55}$ As abolition of the death penalty has become a cornerstone of European human rights policy, central and eastern European countries that aspire to enter the European political and economic system have increasingly calculated that the benefits of joining that system far exceed any benefits that might inure from the occasional use of the death penalty against juveniles. ${ }^{56}$ Thus, from 1994 to 2003, Amnesty International recorded twenty executions of child offenders in only five countries: the Democratic Republic of the Congo, Iran, Pakistan, Nigeria, and--the leader, with thirteen-

\footnotetext{
${ }^{51}$ Lawrence v. State, 41 S.W.3d 349, 361 (2001).

${ }^{52} 478$ U.S. 186, 197 (1986) (Burger, C.J., concurring).

${ }^{53}$ United States v. Sampson, Memorandum and Order, CR No. 01-10384-MLW, 2003 U.S. Dist. LEXIS 14050, at $* 97$ (D. Mass. Aug. 11, 2003) (observing that the fact that the death penalty has been widely abolished abroad "is cognizable evidence of contemporary standards of decency"); seeAdam Liptak, Signs Grow of Innocent People Being Executed, Judge Says, N.Y. TimES, Aug. 12, 2003, at A10.

${ }^{54}$ International Human Rights Treaties: Hearings Before the Senate Comm. on Foreign Relations, 96 th Cong. 55 (1979) (response by the Department of State to the "Critique of Reservations to the International Human Rights Covenants" by the Lawyers Committee for Human Rights).

${ }_{55}$ Reported Executions of Child Offenders Since 1990, tbl., in AMNESTY INTERNATIONAL, THE EXCLUSION OF CHILD OFFENDERS FROM THE DEATH PENALTY UNDER GENERAL INTERNATIONAL LAW \$5 (AI Index No. ACT 50/004/ 2003, 2003) [hereinafter AMNESTYREPORT], available at <http://web.amnesty.org/library/index/engact500042003>.

${ }^{56}$ As the Death Penalty Information Center has chronicled, steps have recently been taken to abolish or impose a moratorium on the death penalty in such countries as Azerbaijan, Bulgaria, Estonia, Georgia, Kyrgyzstan, Latvia, Lithuania, Poland, Russia, Turkey, Turkmenistan, and the former Yugoslavia.
} 
the United States. ${ }^{57}$ Of these, "[t] he only country that openly continues to execute child offenders within the framework of its regular criminal justice system is the USA. ${ }^{58}$ Five of the last seven juvenile offenders executed worldwide have been executed in the United States. ${ }^{59}$ Even within the United States, executions of child offenders since 1977 have been carried out in just seven states, over two thirds of them in Texas and Virginia. Given these facts, any commonsense understanding of a ban against "cruel and unusual punishments" should now include a practice deemed not just unusual, but illegal by all but five countries in the world and all but a few states even in this country. Weighing foreign and international opinion into any evaluation of evolving standards of decency among civilized nations leads inexorably to the conclusion that killing child offenders now violates the Eighth and Fourteenth Amendments to the United States Constitution. Indeed, that was the conclusion of the Missouri Supreme Court in Roperv. Simmons, a case that will be heard by the United States Supreme Court early in the 2004-2005 Term. ${ }^{60}$

More fundamentally, the last Supreme Court Term confirms that two distinct approaches now uncomfortably coexist within our own Supreme Court's global jurisprudence. ${ }^{61}$ The first is a "nationalist jurisprudence," exemplified by the opinions of Justices Scalia and Clarence Thomas. ${ }^{62}$ That jurisprudence is characterized by commitments to territoriality, extreme deference to national executive power and political institutions, and resistance to comity or international law as meaningful constraints on national prerogatives. This line of cases largely refuses to look beyond U.S. national interests when assessing the legality of extraterritorial action. Moreover, these decisions have largely rejected international comity as a reason unilaterally to restrain the scope of U.S. regulation, ${ }^{63}$ and dismiss treaty or customary international law rules as meaningful restraints upon U.S. action. ${ }^{64}$ To deal with perceived exigencies, these rulings have broadly deferred to federal executive power, largely unchecked by judicial oversight, "clear statement" principles, or claims of individual rights. ${ }^{65}$ When advised of foreign legal precedents, these decisions have treated them as irrelevant, or worse yet, an impermissible imposition on the exercise of American sovereignty. ${ }^{66}$

A second, more venerable strand of "transnationalist jurisprudence," now being carried forward by Justices Breyer and Ginsburg, ${ }^{67}$ began with Chief Justice (and former congressional secretary for foreign affairs) John Jay and Chief Justice (and former secretary of state) Marshall,

${ }^{57}$ AMNESTY REPORT, supra note 55.

${ }^{58} I d . \$ 5$.

${ }^{59}$ See State ex rel. Simmons v. Roper, 112 S.W.3d 397 (2003).

${ }^{60}$ Roper v. Simmons (No. 03-633), cert. granted (U.S. Jan. 26, 2004), available at <http://supremecourtus.gov/orders/ courtorders/012604pzr.pdf> (reviewing State ex rel. Simmons v. Roper, 112 S.W.3d 397, 41 1, 413 (2003) (finding "of note that the views of the international community have consistently grown in opposition to the death penalty for juveniles" en route to holding that "the execution of persons for crimes committed when they were under 18 years of age violates 'the evolving standards of decency that mark the progress of a maturing society, " and is thus barred by Eighth and Fourteenth Amendments)).

${ }^{61}$ This analysis builds on earlier discussions in Harold Hongju Koh, On American Exceptionalism, 55 STAN. L. REV. 1479, 1513-15 (2003); Harold Hongju Koh, International Business Transactions in United States Courts, 261 RECUEIL DES COURS 13, 226-34 (1996).

${ }^{62}$ Despite his occasional extrajudicial writings, see, e.g., supra note 32, in his Court opinions Chief Justice Rehnquist remains firmly in the nationalist camp.

${ }^{63}$ See, e.g., Hartford Fire Ins. Co. v. California, 509 U.S. 764 (1993) (rejecting international comity as a bar against the exercise of Sherman Act jurisdiction over foreign reinsurance claims).

${ }^{64}$ See Harold Hongju Koh, The "Haiti Paradigm" in United States Human Rights Policy, 103 YALE L.J. 2391, 2413-23 (1994) (collecting cases).

${ }^{65}$ See generally Harold Hongu KoH, THE National SEcurtiy CONSTTIUTION: SHARING POWER AFTER THE IRANCONTRA AFFAIR 117-49 (1990) (reviewing cases).

${ }^{66}$ See, e.g., Foster v. Florida, 537 U.S. 990,990 n.* (2002) (Thomas, J., concurring in denial of certiorari) ("[T]his Court[] ... should not impose foreign moods, fads, or fashions on Americans.").

${ }^{67}$ Justices Stevens and Souter are also regular members of this camp. Through their extrajudicial statements and opinions of the past Terms, the two "swing Justices," Anthony Kennedy and Sandra Day O'Connor, have also increasingly demonstrated transnationalist leanings. 
"who were familiar with the law of nations and comfortable navigating by it." ${ }^{68}$ In later years, this school was carried forward by Justice Gray in Hilton $v$. Guyot and The Paquete Habana, ${ }^{69}$ and by three members of the Supreme Court-Chief Justice Melville Fuller and Justices David Brewer and William Day-who helped found the American Society of International Law, along with William Howard Taft, who later became president, then chief justice, of the United States. ${ }^{70}$ During the tenure of Chief Justices Earl Warren and Burger, the transnationalist position was championed by Justices William J. Brennan, William O. Douglas, ${ }^{71}$ and-particularly in his famous Sabbatino dissent-Justice Byron White. ${ }^{72}$ And in the Burger and early Rehnquist Courts, the leading transnationalist role was played by Justice Harry Blackmun. ${ }^{73}$

Unlike nationalist jurisprudence, which rejects foreign and international precedents and looks for guidance primarily to national territory, political institutions, and executive power, the transnationalist jurisprudence assumes America's political and economic interdependence with other nations operating within the international legal system. Nor, significantly, do these Justices distinguish sharply between the relevance of foreign and international law, recognizing that one prominent feature of a globalizing world is the emergence of a transnational law, particularly in the area of human rights, that merges the national and the international. ${ }^{74}$ Addressing the American Society of International Law, Justice O'Connor noted that, increasingly, foreign and international law issues are coming before U.S. courts "because international law is no longer confined in relevance to a few treaties and business agreements. Rather, it has taken on the character of transnational law-what Philip Jessup has defined as law that regulates actions or events that transcend national frontiers." ${ }^{.75}$ Similarly, Justice Breyer has noted, time has blurred

the differences between what my law professors used to call comparative law and public international law. ... Formally speaking, state law is state law, but practically speaking, much of that law is national, if not international, in scope. Analogous developments internationally, including the emergence of regional or specialized international legal bodies, tend similarly to produce cross-country results that resemble each other more and more, exhibiting common, if not universal, principles in a variety of legal areas. ${ }^{76}$

In such a transnationalist system, as Justice Breyer has noted, understanding and making reference to foreign constitutional precedents aids U.S. constitutional interpretation, "simply because of the enormous value in any discipline of trying to learn from the similar experience of others." ${ }^{77}$ Under this view, domestic courts must play a key role in coordinating U.S. domestic constitutional rules with rules of foreign and international law, not simply to promote American aims, but to advance the broader development of a well-functioning international

${ }^{68}$ Blackmun, supra note 17 , at 49 .

${ }^{69}$ See supra note 1.

${ }^{70}$ Breyer, supra note 33 , at 265.

${ }^{71}$ Harold Hongju Koh, The Liberal Constitutional Internationalism of Justice Douglas, in "HE SHALL NOT PASS THIS WAY AGAin": The Legacy Of JuSTICE William O. Douglas 297 (Stephen L. Wasby ed., 1990).

${ }^{72}$ See, e.g., Banco Nacional de Cuba v. Sabbatino, 376 U.S. 398, 439 (1964) (White, J., dissenting), discussed in Harold Hongju Koh, Transnational Public Law Litigation, 100 YALE L.J. 2347, 2362-63 (1991).

${ }^{73}$ See Blackmun, supra note 17, at 49. For elaboration of this theme, see Harold Hongju Koh, Justice Blackmun and the World Out There, 104 YALE L.J. 23, 28-31 (1994) (collecting cases).

${ }^{74}$ Compare Harold Hongju Koh, The Globalization of Freedom, 26 YALEJ. INT'L L. 305, 306 (2001) (arguing that “as international legal academics, we must start treating transnational law as its own category. Domestic and international will soon become so integrated that we will no longer know whether to characterize certain concepts as local or global in nature."). See also id. (noting that the metric system, Greenwich Mean Time, and the term "dot.com" have "[a]ll . . . become, over time, genuinely transnational concepts in which a global standard has become fully recognized, integrated, and internalized into the domestic system of nearly every nation of the world").

${ }^{75}$ O'Connor, supra note 33 , at 350.

${ }^{76}$ Breyer, supra note 33 , at 267 (emphasis added).

${ }^{77} I d$. at 266. 
judicial system. In Justice Blackmun's words, U.S. courts must look beyond narrow U.S. interests to the "mutual interests of all nations in a smoothly functioning international legal regime" and, whenever possible, should "consider if there is a course that furthers, rather than impedes, the development of an ordered international system." 78

The nationalist justices reject the transnationalist views on the ground that comparative and international analysis is appropriate only to legislative and constitutional drafting, not to the task of judicial constitutional interpretation. ${ }^{79}$ Yet on reflection, this distinction makes no sense. The U.S. Constitution served as a principal inspiration and model for many foreign and international constitutions and covenants, including the Universal Declaration of Human Rights and the International Covenants on Civil and Political Rights and Economic, Social and Cultural Rights. There remains to this day a "vigorous overseas trade in the Bill of Rights, in international and constitutional litigation involving norms derived from American constitutional law." ${ }^{80}$ Concepts like liberty, equality, and privacy are not exclusively American constitutional ideas but, rather, part and parcel of the global human rights movement. Nor is the United States the world's only civilized society. By their nature, human rights concepts evolve and "[j] udges in different countries increasingly apply somewhat similar legal phrases to somewhat similar circumstances. ${ }^{81}$ Construing U.S. constitutional law by referring to other nations' constitutional drafters, but not their constitutional interpreters, would be akin to operating a building by examining the blueprints of others on which it was modeled, while ignoring all subsequent progress reports on how well those other buildings actually functioned over time. ${ }^{82}$

In Lawrence itself, Justice Scalia argued that Bowers "never relied on "values we share with a wider civilization,' ... but rather rejected the claimed right to sodomy on the ground that such a right was not " 'deeply rooted in this Nation's history and tradition." " 83 He justified Bowers in part because "sodomy was a criminal offense at common law and was forbidden by the laws of the original 13 States when they ratified the Bill of Rights." ${ }^{84}$ But to state the argument that way is to refute it. For, as Justice Scalia earlier conceded, " $[t]$ he Court is quite right that 'history and tradition are the starting point but not in all cases the ending point of the substantive due process inquiry. " 85 Early American law punished not just consensual sodomy, but also idolatry, blasphemy, adultery, and witchcraft, all of which were treated as capital crimes. ${ }^{86}$ In looking to foreign law, the Lawrence Court simply made two obvious comparisons: first, that the right asserted by petitioners had long been accepted as fundamental in other countries; and second, that the State of Texas had demonstrated no more compelling, "legitimate or urgent" state interest in restricting that right than had been demonstrated in any of these sister countries. ${ }^{87}$ What sense does it make to construe evolving, universally recognized constitutional concepts such as "due process" and privacy solely in light of national historical tradition,

${ }^{78}$ Société Nationale Industrielle Aérospatiale v. United States Dist. Court, 482 U.S. 522, 555, 567 (1987) (Blackmun, J., concurring in part).

${ }^{79}$ See, e.g., Printz v. United States, 521 U.S. 898, 921 n.11 (1997); Foster v. Florida, 537 U.S. 990, 990 n.* (2002) (Thomas, J., concurring in the denial of certiorari) (foreign law and practice may be relevant to legislative drafting).

${ }^{80}$ Lester, supra note 46 , at 541 .

${ }^{81}$ Breyer, supra note 33, at 266.

${ }^{82}$ Thus, Professor Ramsey concedes that courts worldwide are engaged in a common exercise of interpreting common legal texts such as the UN Convention on the International Sale of Goods and the Warsaw Convention on air transport liability, while curiously insisting that courts construing various human rights instruments that share a common heritage in the Universal Declaration of Human Rights are interpreting "different documents, written in different times and different countries (and sometimes different languages)." Ramsey, supra note 12, at 73 .

${ }^{83}$ Lawrence, 123 S.Ct. at 2494 (Scalia, J. dissenting) (emphasis in original).

${ }^{84} I d$. at 2492.

${ }^{85} I d$. at 2492 n.3.

${ }^{86}$ Michael H. Reggio, History of the Death Penalty, in SOCIETY's Final Solution: A History and Discussion OF THE DEATH PENALTY 1, 3 (Laura Randa ed., 1997).

${ }^{87}$ Laurrence, 123 S.Ct. at 2483. 
while ignoring strong, contemporary indicia from kindred nations that, in fact, such criminal laws serve slight governmental interests and infringe concepts of personhood that were not fully recognized two centuries ago ${ }^{88}$

Nationalist academics add a second objection, which one dubs the "international countermajoritarian difficulty": the claim that U.S. constitutional protections that are responsive to "national consensus giving expression to the sovereign will of the American people" cannot "be interpreted to give expression to the international majoritarian impulse to protect the individual from democratic governance. ${ }^{89}$ Yet this argument assumes that the job of judges construing the Constitution is to give expression to majoritarian impulses, when their longsettled role (which, of course, gives rise to the domestic countermajoritarian difficulty) has been to apply enduring principles of law to evolving circumstance without regard to the will of shifting democratic majorities. ${ }^{90}$ In effect, the nationalists claim that unelected federal judges may not interpret the Constitution by applying rules made by foreign governments or the world community at the expense of state prerogatives. But obviously, every court in the United States applies law that was not made by its own polity-including foreign law-whenever the court's own choice of law principles so direct.

Nor is there anything necessarily antidemocratic about construing U.S. constitutional law in light of transnational law. As Justice Breyer recently noted:

$[\mathrm{T}]$ he transnational law that is being created is not simply a product of treaty-writers, legislatures, or courts. We in America know full well that in a democracy, law, perhaps most law, is not decreed from on high but bubbles up from the interested publics, affected groups, specialists, legislatures, and others, all interacting through meetings, journal articles, the popular press, legislative hearings, and in many other ways. That is the democratic process in action. Legislation typically comes long after this process has been underway. Judicial decisions, particularly from our Court, work best when they come last, after experience has made the consequences of legislation apparent. ${ }^{91}$

What Justice Breyer describes is what I have elsewhere called "transnational legal process," the process whereby domestic systems incorporate international rules into domestic law through a three-part process of interaction, interpretation, and norm internalization. ${ }^{92}$ Virtually

${ }^{88}$ As Justice Kennedy noted in Lawrence:

[A] lmost five years before Bowers was decided the European Court of Human Rights considered [Dudgeon, ] a case with parallels to Bowers and to today's case... . [and] held that the laws proscribing the conduct were invalid under the European Convention on Human Rights. Dudgeon v. United Kingdom, 45 Eur. Ct. H.R. (1981) P52. Authoritative in all countries that are members of the Council of Europe (21 nations then, 45 nations now), the [Dudgeon] decision is at odds with the premise in Bowers that the claim put forward was insubstantial in our Western civilization.

123 S.Ct. at 2481 (emphasis added).

${ }^{89}$ Alford, Federal Courts, supra note 12, at 785-86. In fact, the very label "international majoritarian" is misleading. For U.S. courts are not deferring to the will of the majority of the world's peoples instead of deferring to American will; rather, our courts are looking to foreign practice for additional evidence of modern standards of decency in a civilized society. See, e.g., State ex rel. Simmons v. Roper, 112 S.W.3d 397 (2003). Significantly, neither Professors Alford nor Ramsey takes the hard-edged position espoused by nationalist Justices Scalia and Thomas in some recent opinions: namely, that international and foreign law precedents are never relevant to U.S. constitutional interpretation, a view that those Justices have sometimes ignored in practice. See cases cited supra notes 27,31 .

90 Justice Kennedy made the point eloquently in Lawrence:

Had those who drew and ratified the Due Process Clauses of the Fifth Amendment or the Fourteenth Amendment known the components of liberty in its manifold possibilities, they might have been more specific. They did not presume to have this insight. They knew times can blind us to certain truths and later generations can see that laws once thought necessary and proper in fact serve only to oppress. As the Constitution endures, persons in every generation can invoke its principles in their own search for greater freedom.

Lawrence, 123 S.Ct. at 2484.

${ }^{91}$ Breyer, supra note 33 , at 268 (emphasis added).

${ }^{92}$ For elaboration of this point, see Harold Hongju Koh, How Is International Human Rights Law Enforced? 74 IND. L.J. 1397 (1999); and Harold Hongju Koh, Bringing International Law Home, 35 Hous. L. REv. 623 (1998); Harold Hongju Koh, Why Do Nations Obey Intermational Law? 106 YALE L.J. 2599 (1997). 
all legal systems identify one or more mechanisms through which executive, legislative, and judicial institutions may domesticate international norms, with judicial interpretation of domestic constitutions representing only one such channel. ${ }^{93}$ Through a time-honored dialogic process, litigants, activists, publicists, and academic commentators seek to inform, influence, and improve this kind of judicial decision making. There is nothing antidemocratic about academics, nongovernmental organizations, judges, executive officials, Congress, and foreign governments interacting in a variety of private and public, domestic and international fora to make, interpret, internalize, and ultimately enforce rules of transnational law. To the contrary, it is precisely through this transnational legal process that interlinked rules of domestic and international law develop, and that interlinked processes of domestic and international compliance come about.

In this transnational legal process, the several states, foreign governments, and international bodies do not represent competing sovereigns, all vying for the right to control America's judicial destiny. Rather, a transnationalist jurisprudence suggests, the United States expresses its national sovereignty not by blocking out all foreign influence but by vigorous "participation in the various regimes that regulate and order the international system. ${ }^{\text {"94 }}$ The nationalists' suggestion that U.S. courts should disregard the rest of the civilized world by ignoring parallel foreign precedents only invites charges of parochialism, and undermines U.S. influence over the global development of human rights.

Nationalist academics charge that American human rights advocates have used international and foreign legal materials selectively; in one commentator's words, refusing to "take the bitter with the sweet," comparison only if they are viewed as rights enhancing." ${ }^{.96}$ Bizarrely, these scholars assume that United States judges should construe a national bill of rights that the framers thought was the model for the world in light of the world's worst practices. What this claim misunderstands is that those who advocate the use of international and foreign sources in U.S. constitutional interpretation are not urging U.S. courts to defer automatically to some kind of global "nose count." Instead, they are suggesting that the practices of other mature democracies-not those that lag behind developmentally-constitute the most relevant evidence of what Eighth Amendment jurisprudence calls the "evolving standards of decency that mark the progress of a maturing society." ${ }^{97}$

My point is simple: those who advocate the use of international law in U.S. constitutional interpretation are not mere "international majoritarians" who believe that American constitutional liberties should be determined by a worldwide vote. Rather, transnationalists suggest that particular provisions of our Constitution should be construed with decent respect for international and foreign comparative law. When phrases like "due process of law," "equal protection," and "cruel and unusual punishments" are illuminated by parallel rules, empirical evidence, or community standards found in other mature legal systems, that evidence should not simply be ignored. Wise American judges did not do so at the beginning of the Republic, and there is no warrant for them to start now.

In any event, Laurence and Atkins may signal that the nationalists' heyday has finally passed. As Justice Breyer recently noted, "By now ... it should be clear that the chicken has broken

\footnotetext{
${ }^{93}$ For a discussion of the appropriate relationship between domestic and international tribunal rulings, see Harold Hongju Koh, Paying Decent Respect to International Tribunal Rulings, 96 ASIL PROC. 45 (2002).

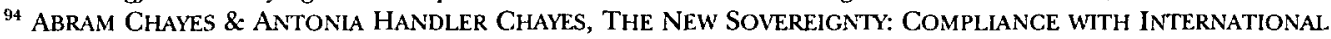
REGULATORY AGREEMENTS 27 (1995).

${ }^{95}$ Ramsey, supra note 12 , at 76-77.

${ }^{96}$ Alford, Misusing Sources, supra note 12, at 67.

${ }^{97}$ Trop v. Dulles, 356 U.S. 86, 101 (1958).
} 
out of the egg." ${ }^{\text {98 }}$ Like it or not, both foreign and international law are already part of our law. In time, I expect, those who continue to deny that reality will be remembered like those who "assumed the attitude once ascribed ... to the British: when told how things are done in another country they simply say "How funny." 99

\title{
MISUSING INTERNATIONAL SOURCES TO INTERPRET THE CONSTITUTION
}

\author{
By Roger P. Alford*
}

In the keynote address to the 2003 annual meeting of the American Society of International Law, Justice Stephen Breyer declared that "comparative analysis emphatically is relevant to the task of interpreting constitutions and enforcing human rights." Justice Breyer concluded that nothing could be "more exciting for an academic, practitioner, or judge than the global legal enterprise that is now upon us." In a room filled with international lawyers and academics, he received a home court standing ovation.

I would hazard that the wider legal academy would not have received Justice Breyer's speech with nearly the same enthusiasm, just as it will not warmly embrace the "remarkable" and "quite extraordinary" ${ }^{3}$ appeal to international sources ${ }^{4}$ that is evident in recent Supreme Court decisions. ${ }^{5}$ For if we accept Justice Breyer's incipient constitutional comparativism, conceding that judges everywhere face the "same kinds of problems ... armed with the same kinds of legal instruments," then we accept a potential "change [to] the course of American law" through expansion of the traditional "canon of authoritative materials from which constitutional common law reasoning might go forward." as encompassing text, structure, history, and national experience. ${ }^{9}$ Including a new source

${ }^{98}$ Breyer, supra note 33 , at 267.

${ }^{99}$ James Michael, Homosexuals and Privacy, 138 NEW L.J. 831, 831 (1988).

*Associate Professor of Law, Pepperdine University School of Law. Earlier versions of these comments were presented at the 2002 annual conference of the American Society of International Law, Section on International Law in Domestic Courts, Fordham University Law School; and the 2003 International Law Society-West symposium at Loyola of Los Angeles Law School. I gratefully acknowledge the comments of the participants at those conferences, as well as the research assistance of David Dae Hoon Kim, Georgetown University Law Center.

'Stephen Breyer, Keynote Address, 97 ASIL PrOC. 265, 265 (2003) (quoting Ruth Bader Ginsburg \& Deborah Jones Merritt, Affirmative Action: An International Human Rights Dialogue, Fifty-first Cardozo Memorial Lecture (Feb. 11, 1999), in 21 CARDOZO L. REV. 253, 282 (1999)).

${ }^{2} I d$. at 268.

${ }^{8}$ Peter Rubin, American Constitution Society Supreme Court Roundup (July 1, 2003), at <http://www.acslaw.org/pdf/ SCOTUStrans.pdf> (describing references to European Court of Human Rights in Supreme Court's Lawrence decision as "remarkable" and "quite extraordinary"); see also Inferior Imports, INVESTOR's BUS. DAILY, July 10, 2003, at A15 (discussing "disturbing" approach in Lawrence of using foreign courts to interpret Constitution); Tony Mauro, Supreme Court Opening up to World Opinion, LEGAL. TIMES, July 7, 2003, at 1, 8 (this year was "breakthrough term" in which "the ostrich's head came out of the sand"). For a particularly sharp critique, see ROBERT H. BORK, COERCING VIRTUE: THE WORLDWIDE RULE OF JUDGES 15-25, 135-39 (2003) (discussing "insidious appeal of internationalism" in constitutional interpretation).

${ }^{4} I$ use the term "international sources" in order to include the full panoply of transnational comparative materials that may be borrowed in the interpretive process, including international and foreign laws and practices.

${ }^{5}$ For a discussion of these cases, see text at notes 21-24, 40-41, 58-61 infra.

${ }^{6}$ Stephen Breyer, Réflexions relatives au principe de fraternité, Address to the 30th Congress of the Association of French-Speaking Constitutional Courts (June 20, 2003), at <http://www.supremecourtus.gov/publicinfo/ speeches/sp_06-20-03.html> ("En un mot on trouve partout des juges faisant face aux mêmes espèces de problèmes et armés des mêmes espèces d'instruments juridiques.").

${ }^{7}$ Anne-Marie Slaughter, A Global Community of Courts, 44 HARV. INT'L L.J. 191, 203 (2003) (discussing potential change resulting from cross-fertilization).

${ }^{8}$ Charles Fried, Scholars and Judges, Reason and Power, 23 HARV.J.L. \& PUB. POL'Y 807, 819 (2000) (discussing Justice Breyer's proposal to use comparative materials in Printz v. United States, 521 U.S. 898 (1997)).

${ }^{9}$ See Philip Bobbitt, Constitutional. Fate: Theory of the Constitution 3-1 19 (1982); LaurenCe H. TRIBE, AMERICAN CONSTITUTIONAL LAW 75 (2000). 